\title{
Evaluation of 3 techniques for determining diet composition
}

\author{
S. R. HENLEY, D. G. SMITH, AND J. G. RAATS
}

Authors are research assistant, Department of Zoology, Terrestrial Ecology Research Unit, University of Port Elizabeth, P.O. Box 1600, South Africa, 6000; research associate, Institute of Cell, Animal and Population Biology, University of Edinburgh, Ashworth Laboratories, The King's Buildings, Edinburgh, EH9 3JT, Scotland; professor, University of Fort Hare, Private Bag X1314, Alice, South Africa, 5700.

\begin{abstract}
A comparative study was made of 3 techniques applied to the study of herbivore diet selection, namely direct observation, faecal analysis and the recently developed remote control oesophageal fistula valve, using 3 animals over 4 study days. Direct observation showed a relatively high level of precision with respect to the woody forage class but a poor measurement of the grass class. The ratios of grass to dicot were similar in the diets determined by direct observation and valve fistulation, but faecal analysis over-emphasised dicots relative to the other techniques. The greatest overlap in estimated diet was between faecal analysis and valve fistulation. Overall the valve fistulation technique was considered superior to the other 2 techniques because it provided reliable estimates of diet composition that could be readily equated to range conditions at the time of ingestion.
\end{abstract}

Key Words: Microhistological analysis, goats, South Africa, Oesophageal fistula

Quantitative analysis of the botanical composition of herbivore diets is generally determined using either direct observation of the foraging animal; examination of epidermal fragments by faecal analysis; or examination of epidermal fragments in oesophageal extrusa (Gordon 1995). Comparisons of these 3 techniques have, in the past, shown poor correlation (Vavra et al. 1978, Sanders et al. 1980, McInnis et al. 1983).

Although both faecal analysis and direct observation can provide reliable estimates of diet composition (Holechek et al. 1982a) oesophageal extrusa is considered to provide a more representative analysis of the actual composition (Forwood et al. 1987) because:

1. Oesophageal extrusa is more truly representative of the diet than direct observation because an animal has actually ingested the sampled forage (Le Du and Penning 1982) thus observer errors are eliminated and bite size need not be estimated.

2. Digestive processes that bias faecal analysis toward indigestible diet constituents are avoided (Vavra and Holechek 1980).

3. Oesophageal extrusa is less likely to be influenced by observer training and capability than faecal analysis (Holechek et al. 1982b).

The authors would like to thank the UK Royal Society for their financial assistance with the preparation of this paper.

Manuscript accepted 17 Nov. 00

\section{Resumen}

Se realizo un ensayo comparativo de 3 técnicas aplicadas para estudiar la selección de la dieta de los hervíboros, las técnicas evaluadas fueron: observación directa, análisis fecal y la recién desarrollada válvula de la fistula esofágica de control remoto; se utilizaron 3 animales en 4 días de estudio. La observación directa mostró un nivel relativamente alto de precisión con respecto a los forrajes leñosos, pero una pobre medida de clase de zacates. Las proporciones de zacates a dicotiledóneas fueron similares en las dietas determinadas por observación directa y la fistulación de válvula, pero el análisis fecal sobrestimo las dicotiledóneas en relación a las otras técnica. El mayor traslape en la dieta estimada se dio entre el análisis fecal y la fistulación de válvula. En general, la técnica de fistulación de válvula se consideró superior a las otras dos técnicas porque provee estimaciones confiables de la composición de la dieta que pudieran ser fácilmente comparadas a las condiciones del pastizal al momento de la ingestión.

Recently however, the reliability of the oesophageal extrusa samples for animals foraging within diverse plant communities has been questioned (Jones and Lascano 1992). The principal source of error is that oesophageal extrusa samples are collected only once per day, generally in the morning, after a period of fast (Coates et al. 1987). The collection of a single sample assumes that diet selection and plant species preferences remain constant throughout the day. As herbivores are likely to pass through several micro-communities of plants throughout the day, this assumption is likely to be ill-founded. Furthermore, animals that have been fasted are unlikely to select the same plants or plant parts as animals that are close to satiety (Jones and Lascano 1992). The poor reliability of oesophageal extrusa from fistulated animals has been demonstrated by Coates et al. (1987) and Jones and Lascano (1992) using a technique that discriminates between tropical legumes and tropical grasses (Ludlow et al. 1976).

The development of a remote controlled oesophageal fistula valve by Raats and Clarke $(1992,1996)$ has allowed oesophageal extrusa samples to be collected throughout the day without having to restrain the fistulated animal. Increasing extrusa sampling frequency with the aid of an oesophageal fistula valve improves the agreement between the grass content of diets measured by the oesophageal extrusa and direct observation techniques (Raats et al. 1996).

The development of the remote controlled oesophageal fistula valve provides an opportunity to re-evaluate the 3 techniques for estimating botanical composition. This paper presents the results of an evaluation study carried out at the University of Fort Hare, South Africa in which the direct observation, faecal analysis and 
oesophageal extrusa (obtained from goats fitted with remote controlled oesophageal fistula valves) techniques were compared.

\section{Materials and Methods}

Each technique was applied concurrently to the same 3-individual Boer goats (Capra hircus). The 3 goats were surgically prepared with oesophageal fistulae according to the technique described by Raats et al. (1996). The large fistula required $\left(1,050 \mathrm{~mm}^{2}\right.$ aperture size) to fit the oesophageal fistula valve was achieved by stretching a standard, surgically established fistula $\left(500 \mathrm{~mm}^{2}\right)$ with progressively larger plastic inserts. Following a 10 week recovery period, which included a 4 week training period to accustom the animals to the equipment and handling procedures, the goats were penned over-night in a holding pen close to the study site and were allowed to forage on a paddock that was similar and adjacent to the study site.

The study site consisted of a single paddock enclosing 1 ha of False Thornveld (Acocks 1975), rested for 1 growing season and situated on the research farm of the University of Fort Hare, South Africa $\left(32^{\circ} 49^{\prime} \mathrm{S}, 26^{\circ} 51^{\prime} \mathrm{E}\right)$ at an altitude of 600 $\mathrm{m}$. Annual rainfall was between $227 \mathrm{~mm}$ and $967 \mathrm{~mm}$, with distinct bimodal peaks in March and October. The vegetation of the area was dominated by thorny shrubs such as Scutia myrtina (Burm. f.) Kurz, Grewia occidentalis L., Acacia karroo Hayne with open areas between bush clumps dominated by grasses species such as Digitaria spp. Sporobolus spp, Themeda triandra Forssk., and Cymbopogon plurinodis (Stapf) Stapf ex Burtt Davy; few forbs were recorded. The study was carried out during winter (August) 1993, when climatic conditions were dry and cold and most plant growth had ceased.

Animals were released into the paddock between 0700 and 0800 hours and then herded back to the holding pens at 1500 hours. All forage eaten during the 15 day study period was consumed during the 8 hour daily grazing period.

\section{Direct Observation}

Direct observation of the goats was carried out using the bite count method described by Risenhoover (1989). A total of 5 days of direct observation were carried out on day $1,4,9,11$, and 15 of the study period. The first day was used to train observers and to identify practical problems with the methodology while the remaining 4 days were used to collect data.
To cover the whole of the 8-hour daily grazing period, direct observation sessions began at 0900 hours and finished at 1500 hours. Starting on the hour, each fistulated goat was observed (for 10 minutes per hour) in a randomly determined sequence. A 5-minute transition period between observations allowed time for the next focal animal to be located, and a 15minute rest period was provided once all 3 animals had been observed to reduce observer fatigue. The distance between animal and observer during direct observation studies was usually within $10 \mathrm{~m}$, but never more than $20 \mathrm{~m}$. Observers recorded animal identity, time of observation, plant species and number of bites. Where the species selected by a goat could not be identified, the bite was recorded as an unidentified grass, forb or woody plant. Observers distinguished bites from exploratory mouthing by the occurrence of both distinct head movement and the sound of the bite, as the use of auditory cues to identify prehension has been shown to give better estimates of bite count (Ungar 1996). If a single bite included more than 1 plant species, a bite was recorded for each species.

To allow comparison with the oesophageal extrusa samples, results obtained by direct observation were grouped into 3, two-hour intervals. These 3 intervals were referred to as the morning (0900-1000 hours), midday (1100-1300 hours) and afternoon (1300-1500 hours) observation sessions.

\section{Faecal collection}

In an attempt to identify faecal pellets that were derived from material ingested during the direct observation and oesophageal extrusa study days, 7-10 g of stained-chopped hay was administered to the goats via the oesophageal fistula, on the morning of each study day immediately prior to their release into the paddock. Two colours of stained hay were used, Basic Fuchsin and Methylene Blue. The colour of hay given to the goats alternated between study days.

Faecal pellets were collected rectally from each goat on the 2 mornings ( 24 and 48 hours after dosing) following each of the 4 study days. This was assumed to be the period of peak output of material derived from forage eaten during the study day (Castle 1956). Faecal pellets from the 2 collections were pooled to provide 1 faecal sample from each animal per study day; a total of 12 samples. The faecal samples were dried at $65^{\circ} \mathrm{C}$, then 5 pellets from each sample were milled through a
$1 \mathrm{~mm}$ screen. Ground faecal pellets were examined for the presence of stained hay to confirm that the material originated from the appropriate sampling day, then stored ready for microhistological analysis.

\section{Oesophageal extrusa collection}

On each of the 4 study days oesophageal extrusa samples were also collected. After the goats had been brought to the study site, the fistula plugs were removed and the remote control receiver harness and battery packs were fitted. Oesophageal extrusa samples were collected hourly (a total of 8 samples daily) by remotely opening the oesophageal fistula valve and allowing the extrusa to fall to the ground. The valve remained open until sufficient extrusa had been collected (1-15 minutes). Once the animal had moved away from the feeding station extrusa samples were collected from the ground (thus reducing grazing disruption to a minimum) and placed in plastic bags and stored on ice. On return to the laboratory, samples were freeze-dried and subsequently milled through a $1 \mathrm{~mm}$ screen. A $2 \mathrm{~g}$ sub-sample was retained for microhistological analysis. Samples were pooled according to sampling times equivalent to the morning, midday and afternoon direct observation sessions (see above) to give 3 oesophageal extrusa samples per animal per study day (36 samples in total).

The morning session of direct observation was compared to oesophageal extrusa collected at 0900 hours and 1000 hours, the midday direct observation session with oesophageal extrusa collected at 1100 hours and 1200 hours and the afternoon direct observation session compared with oesophageal extrusa collected at 1300 hours and 1400 hours.

\section{Microhistological analysis}

A collection of reference slides based on positively identified specimens of all the grass, forb and browse species occurring in the study area was prepared according to the method of Storr (1961), using concentrated nitric acid to remove the mesophyll tissue from the epidermis. A dichotomous key, species descriptions and photomicrograph collection was made from the reference slide library.

Faecal and oesophageal extrusa sample material were prepared, according to the method of Scotcher (1979), again using nitric acid to remove mesophyll tissue. Five slides were made up from each of the nitric acid digested faecal samples and 2 for each of the nitric acid digested fistula samples. Each of the slides was then 
examined by following systematic transects and counting the fragments which fell partly or entirely between parallel lines marked on the slide (the distance between lines was slightly less than 1 field of view), using a binocular compound microscope at between 40x and 200x magnification (Stewart 1967). Transects were at least 1 field of view apart to avoid counting the same plant fragment twice. The first 20 fragments of sufficient size that were encountered on each slide were identified using the key, reference slides and species description (Green 1987), if fragments could not be identified they were recorded as either unidentified grass or dicot species. From each study day, 100 (1 sample per day with 20 fragments from 5 slides) faecal epidermal fragments and 120 (3 samples per day with 20 fragments from 2 slides) oesophageal extrusa epidermal fragments per animal were identified, allowing species comprising more than 5\% of the diet to be identified (Stewart 1967).

Fragments that could not be positively identified were recorded as unidentified grasses or dicots. Eragrostis species could not be identified at species level with confidence so they were grouped together as a genus. To reduce bias toward small readily identifiable fragments, only particles that had an area at least as large as half the field of view at 200x magnification were identified.

\section{Data analysis}

All data collected were expressed as the frequency of which a species was encountered, this allowed direct comparisons of all 3 techniques. In the case of the faecal and oesophageal extrusa samples frequency was calculated by dividing the number of times a species was positively identified in an animal's samples by the total number of microscopic observations made for that animal (expressed as percent). For the direct observation technique frequency was calculated from the number of times a species was included in a bite taken by an animal divided by the total number of bites recorded (expressed as percent). No attempt was made to correct raw data by applying weighted bite counts (Collins and Urness 1983) or differential epidermal digestibilities (Dearden et al. 1975).

The 3 techniques were compared using Kulczynski's similarity coefficient (Smith and Shandruk 1979). Analysis of variance was carried out on arc-sine transformed percentage data for 5 of the most abundant species, using a one-way model with measurement technique as the treatment factor and individual animals as the replicated experimental units. Analysis was carried out using Minitab for windows (Release 12.1)

\section{Results}

The frequency of stained hay fragments in the faecal material during the sampling period (24-48 hours after dosing) was low (median $=16.5$ particles per gram of faeces DM), indicating a lack of synchronicity between samples collected for the faecal analysis and those gathered for the other 2 techniques; peak output of stained particles was between 48 and 72 hours after dosing. However, as similarity coefficients between these techniques changed little during the course of the study, there was probably little variation in the diet composition between days and therefore comparison of faecal samples, oesophageal extrusa and direct observation remains valid. In retrospect synchronicity would have been improved if faecal samples had been collected 48 and 72 hours after dosing.

The occurrence of each species and their rank determined by the oesophageal extrusa, direct observation and faecal analysis techniques is shown in Table 1 . The 10 most abundant species made up 87, 89 and $93 \%$ of the diet measured respectively by the oesophageal extrusa, direct observation and faecal analysis techniques. When the 10 most abundant, positively identified species were ranked (Table 1) distinct differences, both in species occur- rence and rank were evident between techniques. Species composition determined by the faecal analysis and oesophageal extrusa techniques showed the closest similarity with 8 of the 10 most abundant species being common and a Kulczynski's similarity coefficient of 69.3. Species composition determined with faecal analysis and direct observation showed the least similarity with only 5 of the 10 most abundant species being common and a Kulczynski's similarity coefficient of 35.0. The similarity of species composition determined by the oesophageal extrusa and direct observation techniques was 6 of the 10 most abundant species being common and a Kulczynski's similarity coefficient of 46.8 .

Similarity coefficients between direct observation and the other 2 techniques diminished progressively (Table 2 ) with study day, whereas the similarity coefficients between faecal analysis and oesophageal extrusa showed little day-today variation, apart from on day 11 . The variation in the relative abundance of the 5 positively identified species common to all 3 techniques is shown in Figure 1. Faecal analysis showed the least amount of daily variation in diet composition particularly in the grass component of the diet.

Statistical analysis of the relative abundance of each of the 5 forage species common to all 3 methods (Scutia myrtina, Grewia occidentalis, Rhus longispina Eckl. \& Zeyh., Themeda triandra and Sporobolus fimbriatus(Trin.) Nees) using study days as replicates are shown in

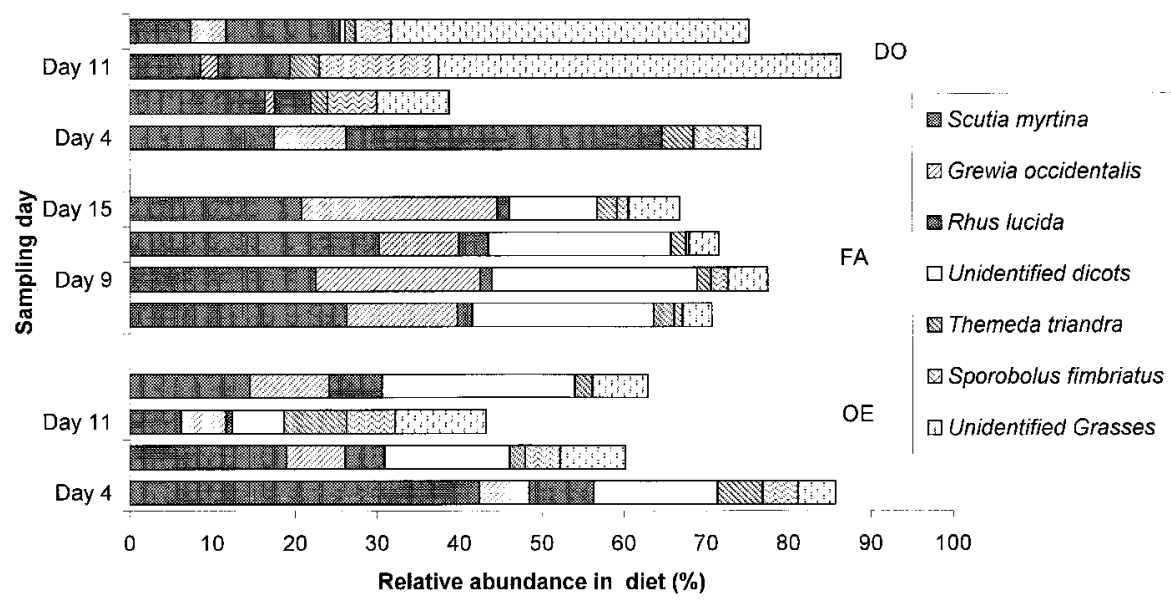

Fig. 1. Variation in the relative abundance (\%) of Scutia myrtina, Grewia occidentalis, Rhus longispina, Themeda triandra, Sporobolus fimbriatus, unidentified grasses and unidentified dicots recorded by direct observation (DO) faecal analysis (FA) and oesophageal extrusa (OE) techniques between four sampling days. 
Table 1. The relative frequency $(\%)$ and rank of species recorded by oesophageal extrusa, direct observation and faecal analysis techniques

\begin{tabular}{|c|c|c|c|c|c|c|}
\hline & $\begin{array}{l}\text { Desophageal } \\
\text { Relative } \\
\text { frequency }\end{array}$ & $\begin{array}{c}\text { Extrusa } \\
\text { Rank }\end{array}$ & $\begin{array}{c}\text { Direct } \\
\text { Relative } \\
\text { frequency }\end{array}$ & $\begin{array}{c}\text { Observation } \\
\text { Rank }\end{array}$ & $\begin{array}{c}\text { Faecal } \\
\text { Relative } \\
\text { frequency }\end{array}$ & $\begin{array}{c}\text { Analysis } \\
\text { Rank }\end{array}$ \\
\hline \multicolumn{7}{|l|}{$\overline{\text { Grasses }}$} \\
\hline Eragrostis spp. & 16.1 & 2 & 0.3 & 20 & 7.4 & 4 \\
\hline Unidentified grasses & 7.5 & 4 & 23.3 & 1 & 5.0 & 5 \\
\hline Digitaria eriantha Steud. & 4.6 & 7 & 0.6 & 18 & 1.1 & 11 \\
\hline Themeda triandra Forssk. & 4.3 & 8 & 2.8 & 8 & 2.2 & 8 \\
\hline Sporobolus fimbriatus(Trin.) Nees & 3.6 & 9 & 8.8 & 5 & 1.1 & 10 \\
\hline Cymbopogon plurinodis (Stapf) & 2.9 & 10 & 7.1 & 6 & 0.0 & - \\
\hline Sporobolus africanus (Poir.) & 1.7 & 12 & 0.0 & - & 0.9 & 13 \\
\hline Heteropogon contortus (L.) P. Beauv. & 0.9 & 16 & 0.0 & - & 0.4 & 18 \\
\hline Panicum maximum Jacq. & 0.6 & 18 & 0.1 & 22 & 0.0 & - \\
\hline Unnamed grass & 0.6 & 19 & 0.0 & - & 0.0 & - \\
\hline Cynodon dactylon (L.) Pers. & 0.3 & 24 & 0.9 & 14 & 0.4 & 17 \\
\hline Aristida congesta Roem. \& Schult. & 0.3 & 25 & 0.0 & - & 0.0 & - \\
\hline Total grass & 43.3 & & 43.8 & & 18.6 & \\
\hline \multicolumn{7}{|l|}{ Dicots } \\
\hline Scutia myrtina (Burm. f.) Kurz & 20.7 & 1 & 13.3 & 3 & 26.2 & 1 \\
\hline Unidentified dicots & 15.0 & 3 & 0.0 & - & 21.4 & 2 \\
\hline Grewia occidentalis L. & 7.2 & 5 & 4.0 & 71 & 7.7 & 3 \\
\hline Rhus longispina Eckl. \& Zeyh. & 5.2 & 6 & 15. & 62 & 2. & 27 \\
\hline Viscum spp. & 1.7 & 11 & 0.9 & 16 & 1.7 & 9 \\
\hline Rhus refracta Eckl. \& Zeyh. & 1.4 & 13 & 0.0 & - & 1.1 & 12 \\
\hline Jasminium spp. & 1.4 & 14 & 0.9 & 15 & 0.0 & - \\
\hline Unnamed dicot 1 & 0.7 & 17 & 0.0 & - & 0.9 & 14 \\
\hline Unnamed dicot 4 & 0.4 & 20 & 0.0 & - & 4.1 & 6 \\
\hline Lippia javanica (Burm f.) Spreng. & 0.4 & 21 & 0.6 & 17 & 0.6 & 15 \\
\hline Ehretia rigida (Thunb.) Druce & 0.4 & 22 & 0.0 & - & 0.4 & 19 \\
\hline Olea europaea $\mathrm{L}$. & 0.3 & 23 & 9.9 & 4 & 0.4 & 16 \\
\hline Rhus undulata var. burchellii (Sond.) Schonl. & 0.3 & 26 & 0.0 & - & 0.0 & - \\
\hline Lycium spp. & 0.1 & 27 & 0.0 & - & 0.0 & - \\
\hline Unnamed dicot 2 & 0.1 & 28 & 0.0 & - & 0.0 & - \\
\hline Unnamed dicot 3 & 0.0 & - & 0.0 & - & 0.0 & - \\
\hline Maytenus heterophylla (Eckl. \& Zeyh.) & 0.0 & - & 0.0 & - & 0.0 & - \\
\hline Unnamed dicot 5 & 0.0 & - & 0.0 & - & 0.2 & 20 \\
\hline Unnamed dicot 6 & 0.0 & - & 0.0 & - & 0.1 & 21 \\
\hline Azima tetracantha Lam. & 0.0 & - & 0.0 & - & 0.0 & - \\
\hline Acacia karroo Hayne & 0.0 & - & 2.3 & 9 & 0.0 & - \\
\hline Diospyros lycioides Desf. & 0.0 & - & 2.3 & 10 & 0.0 & - \\
\hline Protoasparagus spp. & 0.0 & - & 2.3 & 11 & 0.0 & - \\
\hline Coddia rudis (E. Mey. ex Harv.) Verdc. & 0.0 & - & 1.7 & 13 & 0.0 & - \\
\hline Unnamed forb & 0.0 & - & 0.6 & 19 & 0.0 & - \\
\hline Unidentified forbs & 0.0 & - & 0.3 & 21 & 0.0 & - \\
\hline Total dicots & 55.5 & & 54.5 & & 77.1 & \\
\hline \multicolumn{7}{|l|}{ Aloes } \\
\hline Aloe ferox Mill & 1.2 & 15 & 1.7 & 12 & 8.9 & 4 \\
\hline Total number of species observed & 28 & & 22 & & 21 & \\
\hline
\end{tabular}

Figure 2. Differences in relative abundance measured by the oesophageal extrusa and faecal analysis techniques were only significant $(\mathrm{P}>0.05)$ in the case of G. occidentalis, whilst there were no statistically significant differences between relative abundance measured with direct observation and oesophageal extrusa techniques. Differences in relative abundance as measured with direct observation and faecal analysis were significant in all cases apart from the 2 grass species T. triandra and S. fimbriatus.

Analysis of diet composition data in terms of forage type (grass, dicot, or aloe) showed that the direct observation and oesophageal extrusa techniques gave the most similar results (Table 1) with identical proportions of grass, dicot and aloe. The proportion of forage types in the diet determined by faecal analysis showed a greater proportion of dicot and aloe in the diet than the 2 other techniques, perhaps reflecting differences in epidermal digestibility between species.

The relationship between the 3 techniques is shown in Figure 2. Faecal analysis and oesophageal extrusa techniques show closest relationship with one another. Direct observation showed little relationship with the other techniques. However, in all cases there was a closer relationship of data points within than between techniques. Similarity between techniques was consistently lowest between direct observation and faecal analysis and greatest between faecal analysis and oesophageal extrusa (Fig. 2).

\section{Discussion}

Overall the faecal analysis and oesophageal extrusa techniques gave very similar results, showing close similarity in species ranking and in relative frequency. The oesophageal extrusa technique showed greater daily variation in species 


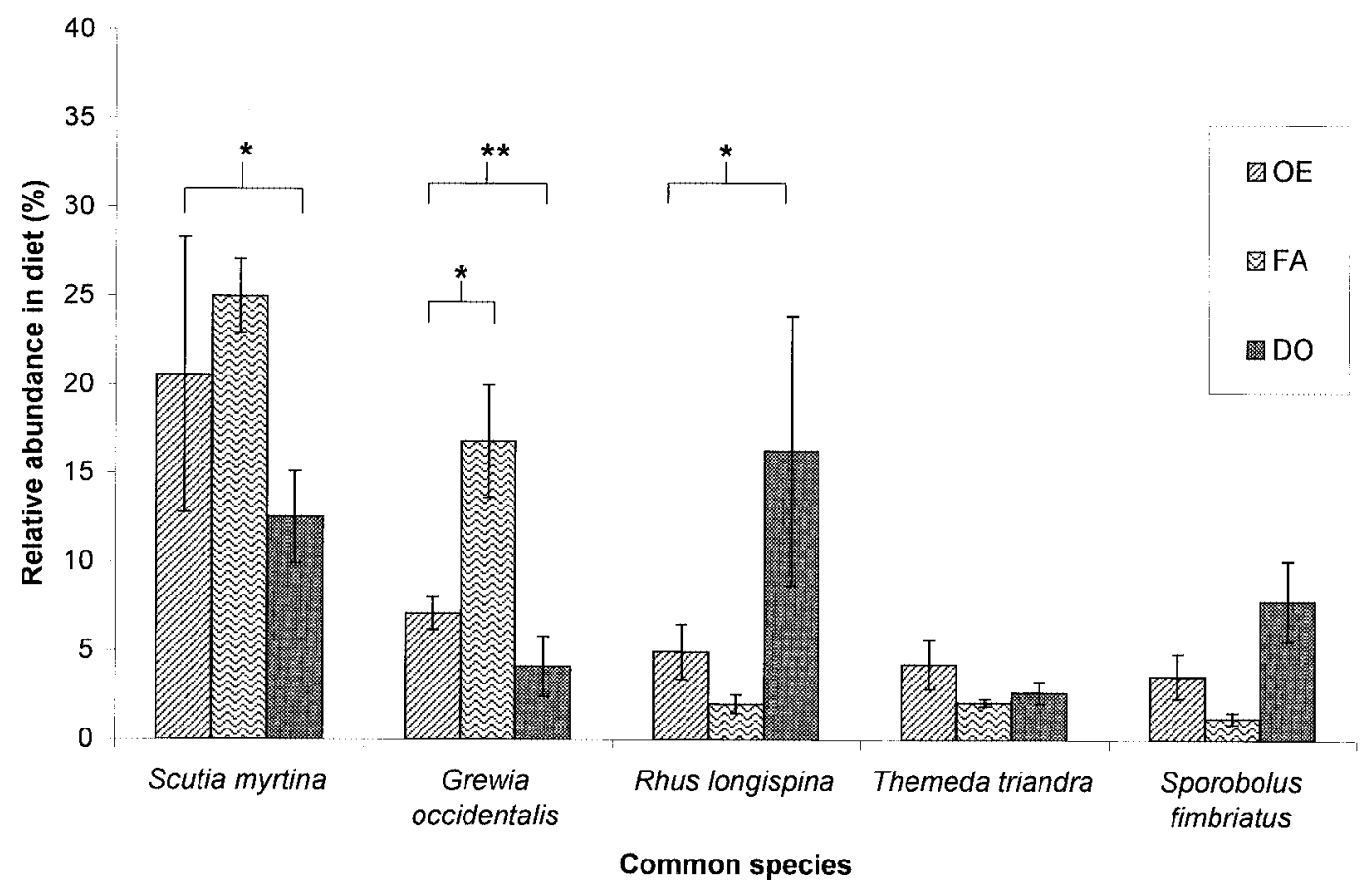

Fig. 2. Comparison of the mean relative abundance (\%), with s.e., of Scutia myrtina, Grewia occidentalis, Rhus longispina, Themeda triandra and Sporobolus fimbriatus recorded by direct observation (DO) faecal analysis (FA) and oesophageal extrusa (OE), indicating significant differences between techniques. $(* \mathrm{P}<0.005, \mathrm{P}<0.01)$

composition of the diet than the faecal analysis technique. However, the difference between faecal analysis and oesophageal extrusa techniques could possibly be due to a different rate of passage of individual species or have been due to the lack of synchronicity between oesophageal extrusa and faecal analysis samples. This also suggests that similarities between techniques in the species ranking and relative frequency were not a consequence of them both being based on microhistological analysis.

Results obtained using the direct observation technique showed poor similarity to both the faecal analysis and oesophageal extrusa techniques. There was good agreement in forage class measurement made by the oesophageal extrusa and direct observation techniques indicating that the high occurrence of unidentifiable grasses recorded by the direct observation technique accounted for much of the lack of similarity between species composition measured by the direct observation and oesophageal extrusa techniques.

The only major difference in similarity coefficients between the faecal analysis and oesophageal extrusa occurred on day 11 of the study (Table 2). This may not necessarily reflect the greater sensitivity of the oesophageal extrusa technique to day-to day changes in diet composition, but may be a result of the small number of oesophageal extrusa samples taken per day. Oesophageal extrusa was sampled on 6 occasions per day, for periods of between 1-15 minutes. The daily oesophageal extrusa samples, therefore, represent forage that was consumed during a 6-90 minute period per day. As the number of unidentified fragments were similar for both faecal analysis and oesophageal extrusa (Table 1), faecal samples are likely to be more representative of the whole period when feed was available, because forages were comminuted and mixed during digestion before being sampled in the faeces. Comparison of the oesophageal extrusa and faecal analysis techniques based on mean relative abundance values from all 4 sampling days were only significantly different in the case of 1 species, G. occidentalis (Fig. 2).

Sampling frequency of oesophageal extrusa is limited because animals need to be provided with the opportunity to feed and the assumption that short-term sampling regimes are representative of the total daily intake may not necessarily be valid, especially in species-rich and patchy plant communities. Whilst the oesophageal extrusa technique has an advantage over the faecal analysis technique that correction factors for epidermal digestibility

Table 2. Comparison of the similarity in species composition (Kulczynski's coefficient) between the direct observations, oesophageal extrusa and faecal analysis techniques on study days 4, 9, 11 and 15.

\begin{tabular}{llc}
\hline \hline Study day & Comparison & Coefficient \\
\hline Day 4 & Direct observation : Faecal analysis & 38.3 \\
& Direct observation : Oesophageal extrusa & 43.6 \\
& Faecal analysis : Oesophageal extrusa & 64.4 \\
Day 9 & Direct observation : Faecal analysis & 33.5 \\
& Direct observation : Oesophageal extrusa & 43.9 \\
& Faecal analysis : Oesophageal extrusa & 65.5 \\
Day 11 & Direct observation : Faecal analysis & 22.4 \\
& Direct observation : Oesophageal extrusa & 33.5 \\
& Faecal analysis : Oesophageal extrusa & 38.2 \\
Day 15 & Direct observation : Faecal analysis & 25.0 \\
& Direct observation : Oesophageal extrusa & 27.6 \\
& Faecal analysis : Oesophageal extrusa & 59.9 \\
\hline
\end{tabular}


direct observation do not have to be applied, results obtained from a single animal on a single day do not necessarily reflect short-term changes in species utilisation.

A major distinction between the direct observation technique and the other 2 techniques was the means used to identify the species. Both the faecal analysis and oesophageal extrusa techniques relied on microhistological analysis of the samples whilst the direct observation technique relied on observers identifying the species in the field. These 2 identification techniques are likely to have distinct sources of error and different levels of both accuracy and precision.

Sensitivity of the direct observation identification method decreased as the study progressed because many of the diagnostic features of grass species, such as flower or seed-heads, diminished as a result of grazing; a similar effect was not evident with the microhistological analysis identification technique. Furthermore, browse and forb species are more readily identified than grasses by the direct observation technique; this results from the great species mix of grasses growing together and the difficulty in recognising individual species from a distance. Moreover, animals tend to spend less time per feeding station when grazing than when browsing, reducing the amount of time available to identify the plants. In the case of the microhistological technique browse and forb species are less readily identified than grasses, because of fewer diagnostic epidermal features

The direct observation technique is also affected by differences in bite size between species unlike with the other 2 techniques. As bite size is largely determined by structural characteristics of the plant (Hodgson 1982), the use of bite count to estimate intake will overestimate the contribution of smaller leafed plants to the diets. Hence $R$. longispina, with leaf dimensions of $10-50 \mathrm{~mm} \times 5-22 \mathrm{~mm}$ (Palgrave 1983), would be expected to have a greater relative frequency in the direct observation determined diet than in the diet determined by the faecal analysis or oesophageal extrusa techniques. Whilst S. myrtina, with leaf dimensions of 35-60 $\mathrm{mm} \times$ 20-40 mm (Palgrave 1983), would be expected to have a lower relative frequency in the direct observation determined diet than in that determined by faecal analysis or oesophageal extrusa techniques. This effect can be seen in the results obtained from this study with the relative frequency of $R$. longispina record- ed by the direct observation, oesophageal extrusa and faecal analysis techniques being $15.6 \%, 5.2 \%$, and $2.2 \%$ respectively, and the relative frequency of S. myrtina recorded by direct observation, oesophageal extrusa, and faecal analysis techniques being $13.3 \%, 20.7 \%$, and $26.2 \%$.

A major difference between the faecal analysis technique and the other 2 techniques was that plant material underwent digestion before being collected. Two possible sources of error could have arisen from the digestive process. Firstly, epidermal particles from different species may have undergone different degrees of digestion during their passage through the gut. Secondly, epidermal fragments from different species may have had different rates of passage through the gut. The process of digestion is generally accepted as having a positive effect on the frequency of grasses and forbs, and a negative effect on the frequency of woody species (Short et al. 1974). However, several studies have shown no effect of digestion on the relative frequency of species in the faeces (Caesbeer and Koos 1970, McInnis et al. 1983). The effect of digestion on the survival of the epidermis is likely to depend on the growth stage of the plant, younger material is less likely to survive than more mature material. In the current study the frequency of grass species was probably negatively effected by digestion, as this forage class was less abundant when measured with faecal analysis than with the other 2 techniques (Table 1). The findings of the present study may reflect the maturity of the leaf material of woody plants at a time of year when no fresh growth was being produced.

The accuracy of the faecal analysis technique may also be affected by the gut transits times of different species fragments. Epidermal fragments of different species within a single faecal sample can, therefore, not be assumed to have been consumed on the same day.

All 3 techniques used in this study have inherent sources of error, and therefore no single technique can provide unequivocal measurements of diet composition. The use of direct observation without taking into account bite size is not likely to provide an accurate quantitative measure of species composition of the diet. The oesophageal extrusa technique can provide very accurate measurement of diet composition over very short sampling periods. The use of oesophageal extrusa technique to describe daily diet composition within species-rich plant communities should be based on an adequate number of daily samples in order to ensure that measure of species diversity is representative. The faecal analysis technique also has inherent errors arising from the passage of forage through the gut. The effects of digestion make it difficult to relate faecal samples to the actual time of ingestion, and variation in the survival of epidermal fragments of different species may adversely effect the accuracy of the quantitative measurement of diet composition.

Further work, using penned animals under controlled conditions, is needed to establish the number of samples required by the oesophageal extrusa technique to obtain accurate measurements of daily diet composition. Comparisons of the oesophageal extrusa, faecal analysis and direct observation also require comparison under controlled conditions where intake of each forage species can be measured, in this way the individual errors associated with each technique can be quantified and possible correction factors developed.

\section{Literature Cited}

Acocks, J.P.H. 1975. Botanical survey of South Africa: No. 40. Veld types of Southern Africa. Dept. Agr., Pretoria.

Caesbeer, R.L. and G.G. Koos. 1970. Food habits of wildebeest, zebra, heartbeest and cattle in Kenya Masailand. East African Wildl. 8: 25-36.

Castle, E.J. 1956. The rate of passage of foodstuffs through the alimentary tract of the goat. British J. Nutr. 10:15-23.

Coates, D.B., P. Schachenmann, and R.J. Jones. 1987. Reliability of extrusa samples collected from steers fistulated at the oesophagus to estimate the diet of resident animals in grazing experiments. Aust. J. Exp. Agr. 27:739-745.

Collins, W.B. and P.J. Urness. 1983. Feeding behaviour and habit selection of mule deer and elk on northern Utah summer range. J. Wildl. Manage. 47:646-663.

Dearden, B.L., R.E. Pegau, and R.M. Hansen. 1975. Precision of microhistological estimates of ruminant food habits. J. Wildl. Manage. 39.402-407.

Forwood, J.R., P. Stypinski, T. Mawhinney, and J.A. Paterson. 1987. Comparison of microscopic and pinitol techniques in determining legume composition of steer diets. Agron. J. 79:996-998.

Gordon, I.J., 1995. Animal-based techniques for grazing ecology. Small Ruminant Res. 16:203-214.

Green, M.J. 1987. Diet composition and quality in Himalayan musk deer based on faecal analysis. J. Wildl. Manage. 51:880-892.

Hodgson, J. 1982. Ingestive behaviour. pp 113 -137. In: J. D. Leaver (Ed.) Herbage Intake Handbook. British Grassl. Soc., Hurley, UK.. 
Holechek, J.L., M, Varva, and R.D. Pieper. 1982a. Botanical composition determination of range diets: a review. J. Range Mange. 35:309-315

Holechek, J.L., B.D. Gross, S. Mady Dabo, and T. Stephenson. 1982b. Effects of sample preparation, growth stage and observation on microhistological analysis. J. Wildl. Manage. 46:502-502.

Jones, R.J. and C.E. Lascano. 1992. Oesophageal fistulated cattle can give unreliable estimates of the proportion of legume in the diets of resident animals grazing tropical pastures. Grass and Forage Sci. 47:128-132.

Le Du, Y.L.P. and P.D. Penning 1982. Animal based techniques for estimating herbage intake. pp 37-75. In J.D. Leaver (Ed.), Herbage Intake Handbook: British Grassl. Soc., Hurley, UK

Ludlow, M.M., J.H. Troughton, and R.J. Jones 1976. A technique for determining the proportion of $\mathrm{C} 3$ and $\mathrm{C} 4$ species in plant samples using stable natural isotopes of carbon. J. Agric. Sci. 87: 625-632.

McInnis, M.L., M. Vavra and W.C. Krueger 1983. A comparison of four methods used to determine the diet of large herbivores. J. Range Manage. 36: 302-307.
Palgrave, K.C. 1983. Botanical Survey of South Africa: No. 40. Trees of Southern Africa. Struik, Cape Town, So. Africa.

Raats, J.G. and B.K. Clarke. 1992. Remote control of oesophageal fistula samples in goats. Small Ruminant Res. 7: 245-251.

Raats, J.G. and B.K. Clarke. 1996. A remote controlled forage sampling system for goats. Bull. Grassl. Soc. of So. Africa. 7(Suppl. 1): 64.

Raats, J.G., C.K. Mogorosi, D. Pepe, L.N. Webber, A.C. Beckerling, and N.M. Tainton. 1996. Evaluation of the fistula valve technique. 2. Observed feeding behaviour vs extrusa composition. Bull. Grassl. Soc. of So. Africa. 7 (Suppl. 1): 66.

Risenhoover, K.L. 1989. Composition and quality of moose winter diets in interior Alaska. J. Wildl. Manage. 53: 568-577.

Sanders, K.D., B.E. Dahl and G. Scoot. 1980. Bite-count vs. faecal analysis for range animal diet. J. Range Manage. 32:146-149.

Scotcher, J.S.B. 1979. A review of faecal analysis techniques for determining the diet of wild grazing herbivores. Proc. Grassl. Soc. of Africa. 14: 131.

Short, H.L., R.M. Blair, and C.A. Segelquist. 1974. Fibre composition and forage digestibility by small ruminants. J. Wildl. Manage. 38:197-209.
Smith, A. D. and L.J. Shandruk. 1979 Comparison of faecal and rumen utilisation methods for ascertaining pronghorn diets. J. Range Manage. 32:275-279.

Stewart, D.R.M. 1967. Analysis of plant epidermis in faeces, a technique for studying the plant preferences of grazing herbivores. J. Appl. Ecol. 4: 83-111.

Storr, G.M. 1961. Microscopic analysis of faeces, a technique for ascertaining the diet of herbivorous mammals. Aust. J. Biol. Sci. 14: $157-164$.

Ungar, E.D. 1996. Ingestive behaviour. pp. 185-218 In J. Hodgson and A.W. Illius (Eds.), The ecology and management of grazing systems CAB International, Wallingford, UK.

Vavra, M. and J.L. Holechek. 1980. Factors influencing microhistological analysis of herbivore diets. J. Range Manage. 33:371-374.

Vavra, M., R.W. Rice, and R.M. Hansen. 1978. A comparison of oesophageal fistula and faecal material to determine steer diets. J. Range Manage. 